\title{
The Effects of Participant Motivational Behavioural Intention: The MARBLE Case
}

\section{Os efeitos da intenção comportamental motivacional do participante: o caso MARBLE}

\author{
Yilmaz Akgunduz \\ DEU, Seferihisar Fevziye Hepkon School of Applied Sciences, İzmir, Turkey, yilmaz.akgunduz@deu.edu.tr \\ Ovunc Bardakoglu \\ DEU, Seferihisar Fevziye Hepkon School of Applied Sciences, İzmir, Turkey, ovunc.bardakoglu@deu.edu.tr \\ Yesim Koba \\ DEU, Seferihisar Fevziye Hepkon School of Applied Sciences, İzmir, Turkey, yesim.koba@deu.edu.tr
}

\begin{abstract}
This study investigates the motivational factors underlying participation in trade fairs, and their effects on participant satisfaction and behavioural intentions. Data were collected through a questionnaire to 608 participants, selected by convenience sampling, at the International Natural Stone and Technologies Fair (MARBLE), held on 22-25 March 2017 in İzmir, Turkey. Confirmatory factor analysis (CFA) was used to verify the convergent and discriminant validity of the scales while multiple regression analyses were used to test the research hypotheses. The results indicate that the trade fair participants were motivated by commercial attractiveness, financial attractiveness, information search, and city attractiveness. Participant satisfaction was significantly influenced by commercial attractiveness, financial attractiveness, and information search while behavioural intentions were determined by city attractiveness and information search.
\end{abstract}

Keywords: Event participation, motivation, behavioural intention, participant motivational behavioural intention.

\section{Resumen}

Este estudo investiga os fatores motivacionais subjacentes à participação em feiras e seus efeitos na satisfação e intenções comportamentais dos participantes. Os dados foram coletados através de um questionário a 608 participantes, selecionados por amostragem por conveniência, na Feira Internacional de Pedras e Tecnologias Naturais (MARBLE), realizada de 22 a 25 de março de 2017 em İzmir, Turquia. A análise fatorial confirmatória (CFA) foi usada para verificar a validade convergente e discriminante das escalas, enquanto análises de regressão múltipla foram usadas para testar as hipóteses da pesquisa. Os resultados indicam que os participantes da feira foram motivados por atratividade comercial, atratividade financeira, busca de informações e atratividade da cidade. A satisfação dos participantes foi significativamente influenciada pela atratividade comercial, atratividade financeira e busca de informações, enquanto as intenções comportamentais foram determinadas pela atratividade da cidade e pela busca de informações.

Palavras-chave: Participação em eventos, motivação, intenções comportamentais, intenção comportamental motivacional do participante.

\section{- - - - - - - - - - - - - - - - - - -}

\section{Introduction}

Event tourism is gradually increasing in importance due to its significant contribution to destinations. The interest and participation of people in regional, national, and international events is increasing every year. Destinations, therefore, organize local, national, or international events to create alternative tourism products, increase the number of tourists, maximize their share of tourism economic benefits, gain a competitive advantage, create employment, improve the destination's infrastructure, increase the welfare of local people, ensure social cohesion, and expand audiences for culture and art. Event tourism can be defined as planning, developing, and marketing activities as a primary or secondary tourist attraction to maximize the number of tourists participating in these activities (Getz, 1997). Events are temporary events, with each activity being unique in terms of duration, organization, management, and participation (Tassiopoulus, 2005).

Events are multidimensional organizations that have many compatibilities with the activities. Organizing and promoting events, such as festivals, shows, fairs, exhibitions, and championships, has become part of urban development strategies worldwide (Richards \& Palmer, 2010). Fairs are among the important activities that need to be addressed in terms of supply and demand. Supply side activities of fairs focus on improving the event itself and promotion processes whereas the demand side is more about the evaluations of consumers, motivations for participation, consumption patterns, and determination of spending (Getz, 2008). Fairs can improve or damage a destination's reputation.

Motivation is an important driver for participants (Hudson, 2000). Significant motivators include the event's organization and the destination's characteristics in that participants are generally satisfied if a fair is well-organized and the destination has enough facilities. Therefore, satisfaction cannot be ignored in the formation of behavioural tendencies. It is also one of the basic elements of loyalty. The main motivation of many trade fair participants is to establish new business contacts. Therefore, the availability of accommodation, gastronomic diversity, or historical, cultural, and natural attractions in the destination where the fair is organized can play an important role in determining how participants evaluate the fair and recommend it to others.

A common tendency is revisiting and recommending a place based on loyalty. According to Prayag et al. (2017), satisfied tourists tend to recommend destinations while Liu et al. (2017) 
concluded that tourist satisfaction determines behavioural tendencies. Anderson et al. (1994) describes behavioural intention as an outcome of satisfaction, while Liu et al. (2005) relate it to revisiting, repurchasing, and recommending to others. Behavioural intention indicates the extent the participant is satisfied and influences the decision to revisit the event. This intention can also take the form of positive or negative word-of-mouth advertising. One of the most important indicators of loyalty is recommending a product or service to others through word-of-mouth communication.

MARBLE (Herbig, Q'Hara \& Palumbo, 1998), the International Natural Stone and Technologies Fair, is a marketing activity for a major industry, which was first held in 1995 in Izmir, Turkey. In 2019, 1,100 companies and 63,314 visitors, 209 of whom were foreign, participated in the fair. It should be worth noting that there were no foreign participants in the first year (IZFAS, 2019). Considering the number of exhibitors and visitors in such an internationally important fair, it is important to explore the motivations that lead businesses and people to participate and determine how motivation factors influence their intention to revisit again and recommend the fair to others. Izmir is an attractive destination and aspires to create a positive image through event tourism. As a major international organization, MARBLE is even more important in terms of destination. Therefore, it is necessary to determine participants' satisfaction levels and behavioural intentions. Accordingly, this study identified the motivational factors underlying MARBLE participation and determined how they affect participant satisfaction and behavioural intentions.

\section{Literature Review}

\subsection{Participant Satisfaction and Behavioural Intentions}

Tourism studies why people travel and how they enjoy themselves, and suggests what should be done based on these evaluations (Yoon \& Uysal, 2005). Motivation is an important variable in tourism as it explains tourist behaviour in terms of the social and psychological factors encouraging people to travel and participate in tourism activities (Cohen et al., 2014; Snepenger et al., 2006). People decide to escape from their daily routine, have different experiences, and see new places. Motivation factors explain the push and pull factors for people to go on vacation (Kozak, 2002) or for tourists (Dann, 1977). Push factors refer to the needs that motivate people to travel, such as curiosity, rest, entertainment, and work. Pull factors include destination characteristics, such as natural beauty, historical texture, lifestyle, and traditions (Baloğlu \& Uysal, 1996; Yoon \& Uysal, 2005). Pull factors create consumer awareness and motivates travel to a destination (Woodside and Lysonski, 1989). To attract tourists, a destination must determine the needs of the potential target audience, and ensure visitor satisfaction so that they revisit and recommend it to others.

Satisfaction is the sense of contentment that the consumer experiences from purchased products or services (Oliver, 1980).
If consumers' expectations are met, then they feel satisfied. (Fornel, 1992). Satisfaction also includes concepts like performance, quality, value, regret, addiction, and re-purchase.

Customer satisfaction is one of the most important factors determining behavioural intentions to re-purchase or recommend (Cronin et al., 2000). Behavioural intention is the expression of satisfaction through recommending the product to others after purchasing and consuming goods or services. If the experience is not pleasant, then the individual may not recommend to others (Zeithaml et al., 1996). Customer loyalty resulting from satisfaction is the willingness to pay more whereas dissatisfaction is related to complaining and abandoning the organisation (Cronin et al., 2000).

Regarding destinations, behavioural intention can be combined with concepts like destination loyalty, desire to revisit, and recommendations to others (Bigne et al., 2001; Castro et al., 2007). The intention to revisit reflects the tourist's desire to go to the destination again while the intention of recommending concerns positive word-of-mouth advertising (Boulding et al., 1993). For destination managers, an important indicator of success is tourists' desire to revisit (Chen and Tsai, 2007). When tourists become loyal customers, costs are reduced, and they recommend the destination to others. Thus, they become a voluntary advertisement tool that promotes the destination.

Customer satisfaction is achieved by fulfilling demands, but this can be a very difficult process. All services received during the visit are considered as a whole, resulting in satisfaction or dissatisfaction (Brody and Cronin, 2001; Varki and Colgate, 2001). Satisfaction involves evaluating the destination's characteristics and can indicate the intention to revisit (Kozak and Rimmigton, 2000; Kozak, 2001). Post-visit evaluations of tourists include the desire to revisit and the intention to recommend (Chen and Tsai, 2007).

\subsection{Fair Participation}

Fairs are business and trade events that promote the destination through social, environmental, and sustainable contributions as well as economic returns (Getz, 2008). Special fairs focus on a specific sector and bring together organizations to exhibit products and services related to this sector (Aymankuy, 2006). Fair and meeting organizations are among the fastest growing events and provide the most profit in the tourism sector (Zhang et al., 2007). Fairs boost accommodation, eating and drinking, entertainment, local transportation, and other spending in the destination (Opperman and Chon, 1997). Compared to tourists, fair participants stay more nights, spend more, and are more likely to contribute to the destination's positive image (Zhang et al., 2007). Therefore, organizing more fairs in a destination can be a good strategy to develop tourism. The strongest motivation for participating is to create a convenient environment for establishing new trade connections. Since the budget of business trips is usually met by firms, participant spending may be quite high (Rittichainuwat and Mair, 2012). 
Fair participants usually include firms who want to establish relations with them (Lee, 2010). Fairs save money and ease communication by providing faster and more effective results through face-to-face communication with customers (Crompton and Mckay, 1997). For visitors, it is important to see new products, compare prices, make the right purchasing decisions, establish new business contacts, and follow the latest technological developments (Rittichainuwat and Mair, 2012). The number of participating companies and visitors tends to be higher if fairs are repeated on the same specific dates every year. It also increases the quantity and quality of fairs held in the destination. The quality of the service provided at these events is just as important as the content. That is, while content is a motivating factor that directs the event, quality service ensures that participants are satisfied and shapes their decision to revisit (Getz et al., 2001).

Like the decision to travel, the motivation of companies or visitors to participate in a fair is related to the organization, the fair, destination characteristics, and opportunity costs (Akgunduz and Coşar, 2018). In addition, the destination's attractiveness and opportunities also influence motivation (Zhang et al., 2007). Participants may pay attention to security, language, behaviour of local people, recreational facilities, variety of accommodation, access, and travel time. Fairs can benefit destinations by attracting visitors in the low season, extending their stay, creating a positive image, increasing awareness about the destination, increasing the efficiency of congress, and contributing to local infrastructure development (Getz et al., 1998).

\subsection{Research Question and Hypotheses}

Participants in trade events, such as trade fairs, expect to benefit from participating. That is, participation is a planned behaviour that results from a cost-benefit analysis. Before performing a behaviour, individuals try to foresee the results by taking available information into account to make an informed decision (Madden et al., 1992). If a behaviour is perceived in a positive way (personal attitude) or if other individuals that they care about (subjective norm) also have a positive attitude, and if perceptions affect the individual's behaviour, then the probability of performing that behaviour increases (Ajzen and Driver, 1992).

The research question (RQ) was developed to identify what motivates participants to participate in the MARBLE fair, specifically their expectations, to make suggestions for both organizing committees and companies with stands in the fair.

$\mathrm{RQ}$. What are the motivating factors underlying participation in MARBLE?

People are drawn to situations and events that make them happy and satisfied and avoid those that cause pain or sadness. Positive feelings, thoughts, and behaviours emerge from a satisfying situation whereas negative emotions, thoughts, and behaviours emerge from dissatisfying situations. Previous research (Akgunduz and Coşar, 2018; Barbeitos et al., 2014; Um et al., 2006; Al and Mohammad, 2014) has demonstrated a positive relationship between satisfaction level and future behaviours, such as revisits and recommendations. Many event management studies (e.g. Dayour and Adongo, 2015; Yoon and Uysal, 2005) indicate that participant satisfaction and behavioural intentions depend on expectations. That is, motivation factors drive satisfaction while participant motivations affect revisit and recommendation intentions. The present study investigates these relationships in the case of MARBLE by testing the following hypotheses:

H1. Motivational factors increase the satisfaction of fair participants.

$\mathrm{H} 1 \mathrm{a}$. Commercial attractiveness increases the satisfaction of fair participants.

H1b. Financial attractiveness increases the satisfaction of fair participants.

H1c. City attractiveness increases the satisfaction of fair participants.

H1d. Information search increases the satisfaction of fair participants.

H2. Motivational factors increase the behavioural intentions of fair participants.

H2a. Commercial attractiveness increases the behavioural intentions of fair participants.

$\mathrm{H} 2 \mathrm{~b}$. Financial attractiveness increases the behavioural intentions of fair participants.

$\mathrm{H} 2 \mathrm{c}$. City attractiveness increases the behavioural intentions of fair participants.

H2d. Information search increases the behavioural intentions of fair participants.

\section{Method}

\subsection{Measurement}

Data were collected through a four-section questionnaire. The first part presented the Participation in Fair Scale developed by Lee et al. (2010) to identify the factors that motivate people to participate in fairs. This 21-item scale has five subscales: commercial attractiveness (CA) (5 items), financial attractiveness (FA) (5 items), information search (IS) (4 items), city attractiveness (CAT) ( 3 items), and travel attractiveness (TA) (4 items). The second part presented the Trade Show Satisfaction Scale developed by Lee (2011) to determine which satisfaction elements have been met by the fair experience. This 7-item scale measures general satisfaction. The third part measured behavioural intention using two items derived from Lam and Hsu (2004). All scales used a five-point Likert-style response format (e.g. $1-$ I do not agree, 5-I completely agree). The fourth part presented demographic questions about 
gender, age, number of previous attendances at the fair, educational status, and type of participation.

\subsection{Sample}

The universe of the research was participants at MARBLE, held on 22-25 March 2017 in İzmir, Turkey. According to official information, 50,218 people from 104 countries participated (IZFAS, 2019). Since the actual number of participants could not be exactly determined, sample size was based on the argument that reliable results can be achieved by including 10 times or more respondents than the number of items in the survey (Kline, 2011). Since the questionnaire form included 35 items, the required sample size was a minimum of 350 participants. Convenience sampling was used for collecting the data. Of the 650 questionnaires distributed, 615 were completed, representing a response rate of $94 \%$. The final sample consisted of 608 valid responses. Of the 608 respondents, $71 \%$ were male (420 people), $71 \%$ were 40 years or younger (418 people), $52 \%$ were participating as a visitor (353 people), $70 \%$ had participated more than twice (409 people), and $50 \%$ had a university degree (291 people).

\section{Results}

There were three phases in the data analysis. In the first phase, confirmatory factor analysis (CFA) was used to verify the convergent and discriminant validity of the motivation, satisfaction, and behavioural intention scales. The internal consistency reliabilities of these scales were evaluated via the commonly accepted cutoff level of 0.70 , based on the recommendations of Hair et al. (2010) and Jöreskog and Sörbom (1996) regarding the calculation of reliability and consistency of scales. In the second phase, correlation analysis was used to describe the relationship between motivational factors, satisfaction, and behavioural intention. In the third phase, two separate multiple regression analyses were performed to test the effects of motivation factors on satisfaction and behavioural intention (Akgunduz and Cin, 2015). Correlation and regression analyses were performed by averaging the valid and reliable constructs.

The convergent and discriminant validity of the overall measurement quality was assessed by CFA (Anderson and Gerbing, 1988). The standardized loads should not fall below 0.50 while t-values should be over 1.96 (Hair et al., 2010). Internal consistency reliability was checked by composite reliability using the cut-off value of 0.70 (Hair et al., 2010).

Three items from the satisfaction scale and seven items from the motivational factors scale were excluded, after which the CFA analysis produced the following final fit statistics: $X^{2}=$ 510.10; $d f=155 ; X^{2} / d f=3.29$; root mean squared error of approximation $(\mathrm{RMSEA})=0.066$ goodness - of fit index $(\mathrm{GFI})=$ 0.91; adjusted goodness-of-fit index (AGFI) $=0.88$; comparative fit index $(\mathrm{CFI})=0.96$; incremental fit index $(\mathrm{IFI})=0.96$; relative fit index $(\mathrm{RFI})=0.93$; parsimony normed fit index $(\mathrm{PNFI})=0.77$; non-normed fit index $(\mathrm{NNFI})=0.95$; normed fit index $(\mathrm{NFI})=0.94$ and standardized root mean square residual $(S R M R)=0.052$. As shown in Table 1, the results indicated a reasonable fit of the original six-factor model to the current data.

Table 1 - Overall reliability of constructs and factor loadings of indicators

\begin{tabular}{|c|c|c|c|c|}
\hline & Standardized loadings & t-values & AVE & CR/Alpha \\
\hline Commercial Attractiveness (CA) & & & .50 & $.798 / .797$ \\
\hline Establishing new partnerships & .69 & 17.62 & & \\
\hline Business contacts & .71 & 18.38 & & \\
\hline Discussing a particular issue / meeting business partners & .75 & 19.41 & & \\
\hline Looking at other companies' products & .67 & 16.96 & & \\
\hline Financial Attractiveness (FA) & & & .65 & $.844 / .840$ \\
\hline Fair participation as a reward & .82 & 22.89 & & \\
\hline Financial Support (free participation) & .88 & 25.18 & & \\
\hline Attending private events/seminars & .70 & 18.78 & & \\
\hline City Attractiveness (CAT) & & & .55 & $.829 / .818$ \\
\hline City image & .67 & 17.69 & & \\
\hline City climate & .86 & 25.07 & & \\
\hline City safety & .83 & 24.03 & & \\
\hline Feasible dates & .58 & 14.81 & & \\
\hline Information Search (IS) & & & .53 & $.771 / .771$ \\
\hline Learning most up-to-date technical knowledge & .79 & 21.37 & & \\
\hline Learning most up-to-date knowledge & .72 & 18.82 & & \\
\hline Desire for learning & .67 & 17.20 & & \\
\hline Satisfaction (SAT) & & & .51 & $.807 / .807$ \\
\hline Fulfilment of business needs & .71 & 18.47 & & \\
\hline Marketing investigation & .73 & 18.93 & & \\
\hline Networking opportunities & .75 & 19.73 & & \\
\hline I am pleased with the trade show & .67 & 17.11 & & \\
\hline Behavioural Intention (BI) & & & .74 & $.847 / .837$ \\
\hline Revisit intention & .93 & 18.82 & & \\
\hline Recommendation to other organizations & .78 & 16.57 & & \\
\hline
\end{tabular}

$\mathrm{X}^{2}=570.10 \mathrm{df}=155 \mathrm{X}^{2} / \mathrm{df}=3.29 \quad \mathrm{RMSEA}=0.066 \quad \mathrm{NFI}=0.94 \mathrm{NNFI}=0.95 \mathrm{PNFI}=0.77 \mathrm{CFI}=0.96$ $\mathrm{IFI}=0.96 \mathrm{RFI}=0.93 \mathrm{GFI}=0.91 \mathrm{AGFI}=0.88 \quad \mathrm{SRMR}=0.052 \mathrm{RMR}=0.069$ $\mathrm{AVE}=$ Average Variance Extracted $\quad \mathrm{CR}=$ Composite Reliability 
$\mathrm{RQ}$ investigated the motivating factors leading people to participate in MARBLE. The CFA results indicated four factors were involved: Commercial Attractiveness (CA), Financial Attractiveness (FA), City Attractiveness (CAT), and Information Search (IS).

Arithmetic means of constructs were calculated for correlation and regression analyses. Table 2 presents the means, standard deviations, and correlations of the variables. Satisfaction and behavioural intentions were significantly and positively correlated with the motivational factors. According to Hair et al. (2010), to ensure the discriminant validity of the factors in the model, the square root of the AVE value for each variable should be larger than the shared relationship coefficients. As Table 2 shows, all discriminant validity values are satisfactory in this case.

Table 2 - Means, Standard Deviations, and Correlation matrix

\begin{tabular}{|c|c|c|c|c|c|c|c|c|}
\hline & Mean & Std. Deviation & 1 & 2 & 3 & 4 & 5 & 6 \\
\hline 2. FA & 3.7612 & 1.00615 & $.469^{* *}$ & $.81^{\mathrm{a}}$ & & & & \\
\hline 4. IS & 3.4420 & 1.01928 & $.269^{* *}$ & $.328^{* *}$ & $.689^{* *}$ & $.73^{a}$ & & \\
\hline 5. SAT & 3.8615 & .69442 & $.249^{* *}$ & $.234^{* *}$ & $.167^{* *}$ & $.254^{* *}$ & $71^{a}$ & \\
\hline 6. BI & 4.0157 & .69237 & $.099^{*}$ & $.145^{* *}$ & $.220^{* *}$ & $.219^{* *}$ & $.455^{* *}$ & $.83^{a}$ \\
\hline
\end{tabular}

a Square root of AVE $\quad * * p<0.01 \quad * * * p<0.001$

$\mathrm{CA}=$ Commercial Attractiveness, $\mathrm{FA}=$ Financial Attractiveness, $\mathrm{CAT}=$ City Attractiveness

$\mathrm{IS}=$ Information Search, SAT = Satisfaction, $\quad \mathrm{BI}=$ Behavioural Intention

Three multiple regression analysis were performed to test the hypotheses. Table 3 summarizes the results of the multiple regression analysis to determine the level of effect of the independent variables (CA, FA, CAT, and IS) on the dependent variables (satisfaction and behavioural intention). The Durbin Watson (D-W) statistic was used to identify significant differences between the variables in terms of tolerance value, variance magnification factor (VIF), and condition index (CI), and to assess whether there was auto-correlation.

The first regression analysis shows that $10 \%$ of the elements explained the motivation factors of the participants to satisfaction (Table 3). VIF values were between 1.322 and 2.026 while the $\mathrm{Cl}$ values were between 8.354 and 14.214, which indicates that the variables did not have multiple linear connectivity problems. In addition, the D-W value of 1.753 in the regression model proves that there was no autocorrelation. The results also show that $C A(\beta=0.118)$, FA ( $\beta=$ $0.080)$, and IS $(\beta=0.160)$ significantly increased participant satisfaction whereas CAT did not. Therefore, $\mathrm{H} 1 \mathrm{a}, \mathrm{H} 1 \mathrm{~b}$, and $\mathrm{H} 1 \mathrm{~d}$ can be accepted whereas $\mathrm{H} 1 \mathrm{c}$ is rejected. Based on these values, the regression equation can be written as follows (Constant= 2.771):

$\mathrm{Y}($ Satisfaction $)=2.771+[0.118(\mathrm{CA})+0.08(\mathrm{FA})+0.16(\mathrm{IS})]$

Table 3 - Multiple Regression Analysis of Satisfaction

\begin{tabular}{|c|c|c|c|c|c|c|c|c|}
\hline & \multicolumn{2}{|c|}{$\begin{array}{l}\text { Unstandardized } \\
\text { Coefficients }\end{array}$} & \multirow{2}{*}{$\begin{array}{c}\text { Standardized } \\
\text { Coefficients }\end{array}$} & \multirow[t]{2}{*}{$\mathbf{t}$} & \multirow[t]{2}{*}{ Sig. } & \multirow[t]{2}{*}{ Condition Index } & \multicolumn{2}{|c|}{$\begin{array}{l}\text { Collinearity } \\
\text { Statistics }\end{array}$} \\
\hline & $\beta$ & Std. Error & & & & & Tolerance & VIF \\
\hline (Constant) & 2.771 & .137 & & 20.290 & .000 & 1.000 & & \\
\hline $\mathrm{CA}$ & .118 & .033 & .160 & 3.625 & .000 & 8.354 & .756 & 1.322 \\
\hline FA & .080 & .031 & .116 & 2.550 & .011 & 11.768 & .716 & 1.396 \\
\hline CAT & -.062 & .038 & -.090 & -1.647 & .100 & 13.246 & .493 & 2.026 \\
\hline IS & .160 & .036 & .236 & 4.423 & .000 & 14.214 & .519 & 1.925 \\
\hline
\end{tabular}

Dependent Variable: Satisfaction

$R=0.334 ; R^{2}=0.112 ; \Delta R^{2}=0.106 ; F=18.975 ;$ Sig.= 0.001; Durbin-Watson=1.753

The second regression analysis tested the effect of motivational factors on behavioural intention (Table 4). This analysis indicated that $5 \%$ of the variation in participants' behavioural intentions to revisit MARBLE was explained by their motivation to participate. VIF values were between 1.322 and 2.026 while $\mathrm{Cl}$ values were between 8.354 and 14.214 , which indicates that the variables did not have multiple linear connectivity problems. In addition, the D-W value of 1.78 in the regression model proves that there was no auto-correlation. CAT $(\beta=0.078)$ and $C F(I S=0.082)$ significantly increased behavioural intention whereas CA and FA had no significant effects. Thus, $\mathrm{H} 1 \mathrm{C}$ and $\mathrm{H} 1 \mathrm{~d}$ can be accepted whereas $\mathrm{H} 1 \mathrm{a} \mathrm{H} 1 \mathrm{~b}$ is rejected. Based on the significant effects of the independent variables on the dependent variable, the regression equation can be written as follows (Constant $=3.299$ ):

$\mathrm{Y}($ Behavioural Intention $)=3.299+[0.08(\mathrm{CAT})+0.082$ (IS) $]$ 
Table 4 - Multiple Regression Analysis of Behavioural Intentions

\begin{tabular}{|c|c|c|c|c|c|c|c|c|}
\hline & \multicolumn{2}{|c|}{$\begin{array}{c}\text { Unstandardized } \\
\text { Coefficients }\end{array}$} & \multirow{2}{*}{$\begin{array}{c}\begin{array}{c}\text { Standardized } \\
\text { Coefficients }\end{array} \\
\beta \\
\end{array}$} & \multirow[t]{2}{*}{$t$} & \multirow[t]{2}{*}{ Sig. } & \multirow{2}{*}{$\begin{array}{l}\text { Condition } \\
\text { Index }\end{array}$} & \multicolumn{2}{|c|}{$\begin{array}{c}\text { Collinearity } \\
\text { Statistics }\end{array}$} \\
\hline & $\beta$ & Std. Error & & & & & Tolerance & VIF \\
\hline (Constant) & 3.299 & .140 & & 23.552 & .000 & 1.000 & & \\
\hline $\mathrm{CA}$ & .001 & .033 & .002 & .034 & .973 & 8.354 & .756 & 1.322 \\
\hline FA & .042 & .032 & .061 & 1.317 & .188 & 11.768 & .716 & 1.396 \\
\hline CAT & .078 & .039 & .113 & 2.019 & .044 & 13.246 & .493 & 2.026 \\
\hline IS & .082 & .037 & .120 & 2.196 & .028 & 14.214 & .519 & 1.925 \\
\hline
\end{tabular}

Dependent Variable: Behavioural Intentions

$R=0.246 ; R^{2}=0.060 ; \Delta R^{2}=0.054 ; F=9.677 ; \mathrm{Sig}=0.001 ;$ Durbin-Watson=1.780

\section{Conclusions and Recommendations}

This study explored why people participate in the MARBLE trade fair in Izmir, Turkey. More specifically, it assessed their general satisfaction, intention to revisit, and intention to recommend to others, and determined how these outcomes are affected by specific motivational factors. Four out of five factors motivated individuals to participate: commercial attractiveness, financial attractiveness, city attractiveness, and information search. These motivational elements were previously discussed by Lee et al. (2010), Lin et al. (2016), Oppermann and Chon (1997), Wamiri, (2016), and Zhang et al. (2007).

As predicted, Izmir is an attractive destination, which motivated participation in the fair. This indicates that public and private organizations preparing such fairs should consider destination characteristics to maximize the number of visitors. As Waitt (2003) shows, destination characteristics, such as accessibility, accommodation facilities, historical, cultural and natural assets, gastronomic wealth, and entertainment opportunities, encourage participants to participate in fairs. Destinations with a strong image become the centre of attraction for more activities while such a destination's prestige is strengthened by holding events there (Getz, 2008; Hall, 1992). In addition, potential participating companies are affected by the fair's trade attractiveness, which depends on who participates in the fair. Thus, publicizing on the fair's website which companies have participated in previous years may encourage future commercial participants. Although businesses generally have larger budgets than households, these are not unlimited. Therefore, the attractiveness of the fair affects participation, so organizers should increase this through various facilitators.

Many previous studies have demonstrated a positive relationship between satisfaction and behavioural intentions (Akgunduz and Coşar, 2018; Cakici et al., 2019; Kim et al., 2015; Lee et al., 2011; Sim and Lee, 2013). In the present study, three motivational factors increased participant satisfaction: commercial attractiveness, financial attractiveness, and information search. Thus, meeting participant expectations and having a sufficient budget are important factors increasing the intention to revisit. When participants meet outside the fair, they meet more customers, suppliers, and competitors, thereby achieving their business aims. The same satisfaction factors promoting intention to revisit also determined intention to recommend MARBLE to others. Thus, fair organizers must ensure that these elements are adequately met. Business decisions are made through cost-benefit assessments. That is, participants should believe that the benefit outweighs the cost when persuading others to visit the fair.

Participation in the fair affects city attractiveness, commercial attractiveness, information search, and financial attractiveness. For example, if participants are motivated by financial attractiveness, then their satisfaction may increase if their participation costs are in line with their expectations. Cost expectations affect satisfaction because costs are more measurable and controllable whereas the benefits are harder to predict.

\section{Limitations and future research}

This study has several limitations. First, because the universe was limited to MARBLE participants, the results and recommendations cannot be generalized to other events. Second, random sampling would have been preferable. Finally, future studies of the relationship between satisfaction elements and behavioural intentions of participants in other kinds of fairs (e.g. agriculture, furniture, careers, bridal, jewellery) will allow the research findings of this study to be compared.

\section{References}

Ajzen, I. and Driver, B. L. (1992). Application of the theory of planned behavior to leisure choice. Journal of Leisure Research, 24, 207-224.

Akgunduz, Y. \& Coşar, Y. (2018). Motivations of event tourism participants and behavioral intentions. Tourism and Hospitality Management, 24(2), 1-17.

Akgunduz, Y. \& Cin, F.M. (2015). Job embeddedness as a moderator of the effect of manager trust and distributive justice on turnover intentions. Anatolia, 4, 549-562.

Al, B.A.M. \& Mohammad, H. (2014). Examining tourist's satisfaction, loyalty and intention to revisit. International Journal of Management Sciences, 2(6), 260-273.

Anderson, J. C. \& Gerbing, D. W. (1988). Structural equation modeling in practice: A review and recommended two-step approach. Psychological Bulletin, 103(5), 411-423. https://doi.org/10.1037/00332909.103.3.411

Aymankuy, Y. (2006). Kongre Turizmi ve Fuar Organizasyonları. Ankara: Detay Yayıncılık.

Baloglu, S. \& Uysal, M. (1996). Market segments of push and pull motivations: a canonical correlation approach. International Journal of Contemporary Hospitality Management, 3(8), 32-38.

Barbeitos, I.M., Valle, P.O., Guerreiro, M. \& Mendes, J. (2014). Visitors' motivations, satisfaction and loyalty towards Castro Marim medieval fair. Journal of Spatial and Organizational Dynamics, 2(1), 89-104.

Bigné, J.E., Sánchez, M.I. \& Sánchez, J. (2001). Tourism image, evaluation variables and after purchase behaviour: inter-relationship. Tourism Management, 22(6), 607-616. 
Boulding, W., Kalra, A., Staelin, R. \& Zeithaml, V.A. (1993). A dynamic process model of service quality: from expectations to behavioral intentions. Journal of Marketing Research, 30, 7-27.

Brady, M.K. \& Cronin, J.J. Jr (2001). Some new thoughts on conceptualizing perceived service quality: a hierarchical approach. Journal of Marketing, 65, 34-49.

Cakici, C., Akgunduz, Y. \& Yıldırım, O. (2019). The impact of perceived price justice and satisfaction on loyalty: the mediating effect of revisit intention. Tourism Review, 74 No.3, 443-462.

Castro CB, Armario EM \& Ruiz DM (2007). The influence of market heterogeneity on the relationship between a destination's image and tourists' future behavior.Tourism Management, 28, 175-187.

Chen, C. F. \& Tsai, D. (2007). How destination image and evaluative factors affect behavioral intentions? Tourism Management, 28(4), 1115-1122.

Cohen, S. A., Prayag, G. \& Moital, M. (2014). Consumer behaviour in tourism: Concepts, influences and opportunities. Current Issues in Tourism, 17(10), 872-909.

Crompton, J.L. \& McKay, S.L. (1997). Motives of visitors attending festival events. Annals of Tourism Research, 24(2), 425-439.

Cronin, J.J., Brady, M.K., \& Hult, G.T. (2000). Assessing the effects of quality, value, and customer satisfaction on consumer behavioral intentions in service environments. Journal of Retailing, 76(2), 193218.

Dann, Graham M.S. (1977). Anomie, ego-enhancement and tourism. Annals of Tourism Research, 4(4), 184-94.

Dayour, F. \& Adongo, C.A. (2015). Why they go there: International tourists' motivations and revisit intention to Northern Ghana. American Journal of Tourism Management, 4(1), 7-17.

Fornell C. (1992). A national customer satisfaction barometer: the Swedish experience. Journal of Marketing, 56, 6-21.

Getz D. (2008). Event tourism: definition, evolution, and research. Tourism Management, 29(1), 403-428.

Getz, D., Anderson, D. \& Sheehan, L. (1998). Roles, issues and strategies for convention and visitors bureaux in destination planning and product development: A survey of Canadian bureaux. Tourism Management, 19(4), 331-340.

Getz, D., O'Neill, M. \& Carlsen, J. (2001). Service quality evaluation at events through service mapping. Journal of Travel Research, 39, 380390.

Ha, Y.W. \& Park, M.C. (2013). Antecedents of customer satisfaction and customer loyalty for emerging devices in the initial market of Korea: an equity framework. Psychology and Marketing, 30(8), 676-689.

Hair, J. F., Black, W. C., Babin, B. J., \& Anderson, R. E. (2010). Multivariate data analysis a global perspective. New Jersey: Pearson.

Hall, C. M. (1992). Hallmark Tourist Events: Impacts, Management, and Planning, London: Belhaven Press.

Herbig, P., Q'Hara, B. \& Palumbo, F.A. (1998). Trade show: Who, what, why. Marketing Intelligent \& Planning, 16 (7), 425-435.

IZFAS (2019). MARBLE İzmir Fair. Retrieved 12.09.2019 from https://marble.izfas.com.tr

Jöreskog, K.G. \& Sörbom, D. (1993). LISREL 8: Structural Equation Modelling with the SIMPLIS Command Language. USA: Scientific Software International.

Kim, Y.H., Duncan, J, \& Chung, B.W. (2015). Involvement, satisfaction, perceived value, and revisit intention: a case study of a food festival. Journal of Culinary Science \& Technology, 13(2), 133-158.

Kline, R.B. (2011). Principles and practice of structural equation modelling. New York: Guilford Publications.

Kozak, M. (2001). Repeaters' behaviour at two distinct destinations. Annals of Tourism Research, 28(3), 784-807.

Kozak, M. \& Rimmington, M. (2000). Tourist satisfaction with Mallorca, Spain, as an off-season holiday destination. Journal of Travel Research, 38(3), 260-269.
Kozak, Metin, (2002). Destination benchmarking. Annals of Tourism Research, 29(2), 497-519.

Lam, T. \& Hsu, C.H.C. (2006). Predicting behavioral intention of choosing a travel destination. Tourism Management, 27(4), 589-599.

Lee, E.,(2010). Technological fair use. Southern California Law Review, 83, 797.

Lee, J.H., Kim, H.D., Ko, Y.J. \& Sagas, M. (2011). The influence of service quality on satisfaction and intention: A gender segmentation strategy. Sport Management Review, 14, 54-63.

Lee, M.J., Yeung, S. \& Dewald, B. (2010). An exploratory study examining the determinants of attendance motivations as perceived by attendees at Hong Kong exhibitions. Journal of Convention \& Event Tourism, 11(3), 195-208.

Lee, Y.K. (2011). A cultural perspective on motivation factors affecting exhibition participation. UNLV Theses, Dissertations, Professional Papers, and Capstones. 1100.

Lin, Y. K., Kerstetter, D., \& Hickerson, B. (2016). Constructing a trade show exhibitor satisfaction scale from a stakeholder perspective. Journal of Tourismology, 2(2), 13-35.

Madden, T.J., Ellen P.S \& Ajzen, I. (1992). A comparison of the theory of planned behavior and the theory of reasoned action. Personality and Social Psychology Bulletin, 18(1), 3-9.

Mensah, C. (2013). Residents' satisfaction and behavioral Intention with asogli yam festival in Ghana. International Journal of Asian Social Science, 3(3), 682-702.

Oliver, R.L. (1980). A cognitive model of the antecedents and consequences of satisfaction decisions. Journal of Marketing Research, 17(4), 460-469.

Oppermann, M. and Chon, K. (1997). Convention participation decisionmaking process. Annals of Tourism Research, 24(1), 178-191.

Öztürk, Y. and Şahbaz, R.P. (2017). Algılanan destinasyon imajının tekrar ziyaret niyeti ve tavsiye davranışı üzerine etkisi: Ilgaz Dağı milli Parkı'nda bir araştırma. Journal of Tourism and Gastronmy Studies, 5(2), 3-21.

Quintal, V.A. \& Polczynski, A. (2010). Factors influencing tourists' revisit intentions. Asia Pacific Journal of Marketing and Logistics, 22(4), 554578.

Richards, G. \& Palmer, R. (2010). Eventful Cities: Cultural management and urban revitalisation. Oxford: Butterworth-Heinemann.

Rittichainuwat, B. and Mair, J. (2011). Visitor attendance motivations at consumer travel exhibitions. Tourism Management, 33(5), 1236-1244.

Rodekamp, V. (2005). On the History of Trade Fairs in Germany and Europe. Trade Show Management: Planning, Implementing and Controlling Trade Shows. In Manfred Kırchgeorg, Werner M. Dornscheidt, Wilhem Giese and Norbert Stoeck (Eds), Handbuch Messemanagement: Planung, Durchführung und Kontrolle von Messen, Kongressen und Events (pp. 5-14), Germany: Gabler.

Sim, K.W. \& Lee, J.H. (2013). An examination of visitors' satisfaction on revisiting intention and recommendations: A case study of the national natural recreation forests in Korea. Forest Science and Technology, 9(3), 126-130.

Snepenger, D., King, J., Marshall, E. \& Uysal, M. (2006). Modeling IsoAhola's motivation theory in the tourism context. Journal of Travel Research, 45(2), 140-149.

Thusyanthy, V.and Tharanikaran, V. (2017). Antecedents and outcomes of customer satisfaction: a comprehensive review. International Journal of Business and Management, 12(4), 144-156.

Um, S., Chon, K. \& Ro, Y. (2006). Antecedents of revisit Intention. Annals of Tourism Research, 33(4), 1141-1158.

Varki, S. and Colgate, M. (2001). The role of price perceptions in an Integrated model of behavioral intentions. Journal of Service Research, 3(3), 232-240.

Wamiri, J. (2016). Determınants of customer satisfaction among exhibitors at the Nairobi international trade fair in Kenya. Unpublished Master Thesis, University Of Nairobi. 
Woodside, A.G. \& Lysonski, S. (1989). A general model of traveller destination choice. Journal of Travel Research, 27(4), pp. 8-14.

Wu, I.L. (2013). The antecedents of customer satisfaction and its link to complaint intentions in online shopping: An integration of justice, technology, and trust. International Journal of Informational Management, 33, 166-176.

Yoon, Y. and Uysal, M. (2005). An examination of he effects of motivation and satisfaction on destination loyalty: a structural model. Tourism Management, 26, 45-56.

Yoon, Y. \& Uysal, M. (2005). An examination of the effects of motivation and satisfaction on destination, loyalty: A structural model. Tourism Management, 26(1), 45-56. http://dx.doi.org/10.1016/j.tourman.2003.08.016

Zeithaml, V. A., Berry, L.L. \& Parasuraman, A. (1996). The behavioral consequences of service quality. Journal of Marketing Management, 60, 31-46.

Zhang, H. Q., Leung, V. and Qu, H. (2007). A refined model of factors affecting convention participation decision-making. Tourism Management, 28(4), 1123-1127.

Received: 12.01 .2020

Revisions required: 23.05 .2020

Accepted: 07.07.2020 